\title{
Design and Synthesis of a
} Biochar-Supported Nano Manganese Dioxide Composite for Antibiotics Removal From Aqueous Solution

\section{OPEN ACCESS}

Edited by:

Baharak Sajjadi,

University of Mississippi,

United States

Reviewed by:

Isaac Dennis Amoah,

Durban University of Technology,

South Africa

Zacharias Frontistis,

University of Western Macedonia,

Greece

*Correspondence:

Xiaoxi Cai

xiaoxi@hnu.edu.cn

Specialty section:

This article was submitted to Water and Wastewater Management,

a section of the journal

Frontiers in Environmental Science

Received: 04 March 2020

Accepted: 01 May 2020

Published: 22 May 2020

Citation:

Li J, Cai X, Liu Y, Gu Y, Wang H, Liu S, Liu S, Yin Y and Liu S (2020)

Design and Synthesis of a

Biochar-Supported Nano Manganese Dioxide Composite for Antibiotics

Removal From Aqueous Solution.

Front. Environ. Sci. 8:62.

doi: 10.3389/fenvs.2020.00062

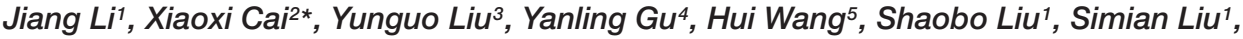 \\ Yicheng Yin ${ }^{3}$ and Sijia Liu ${ }^{3}$
}

\begin{abstract}
'School of Architecture and Art, Central South University, Changsha, China, ${ }^{2}$ College of Art and Design, Hunan First Normal University, Changsha, China, ${ }^{3}$ College of Environmental Science and Engineering, Hunan University, Changsha, China,

${ }^{4}$ College of Materials Science and Engineering, Changsha University of Science and Technology, Changsha, China, ${ }^{5}$ College of Environmental Science and Engineering, Central South University of Forestry and Technology, Changsha, China
\end{abstract}

Manganese dioxide nanoparticles were loaded onto biochar prepared from rice husk to obtain a biochar-supported manganese dioxide composite $\left(\mathrm{BC} / \mathrm{MnO}_{2}\right)$. The properties of this composite were studied through various advanced characterization techniques, combined with experiments on treating aqueous solutions of tetracycline hydrochloride (TC) and doxycycline (DC). The results showed that compared with the original biochar, $\mathrm{MnO}_{2}$ nanoparticles appeared on the surface of $\mathrm{BC} / \mathrm{MnO}_{2}$, the carbon content decreased, and the oxygen content increased. Moreover, $\mathrm{BC} / \mathrm{MnO}_{2}$ exhibited significantly larger total pore volume and specific surface area, and the pore structure of the biochar was improved. The effect of $\mathrm{pH}$ on the adsorption of $\mathrm{TC}$ and $\mathrm{DC}$ by $\mathrm{BC} / \mathrm{MnO}_{2}$ was insignificant. With an increase in the adsorbent dose, the removal rates of $\mathrm{TC}$ and $\mathrm{DC}$ increased, and the removal ability of $\mathrm{BC} / \mathrm{MnO}_{2}$ for $\mathrm{TC}$ was slightly higher than that for $\mathrm{DC}$. The adsorption of $\mathrm{TC}$ and $\mathrm{DC}$ on the $\mathrm{BC} / \mathrm{MnO}_{2}$ surface conformed to the Freundlich model. Compared with the pseudo-first-order kinetic model, the pseudosecond-order kinetic model $\left(R^{2}=0.999\right)$ better fitted the adsorption data, indicating that the adsorption process is controlled by chemical adsorption. In addition, the results of adsorption-desorption experiments indicated that $\mathrm{BC} / \mathrm{MnO}_{2}$ have excellent regeneration ability. The experimental results of this study are significant for expanding the application of biochar composites in the treatment of aqueous solution containing antibiotics.

Keywords: biochar, composite, adsorption, tetracycline hydrochloride, doxycycline

\section{INTRODUCTION}

Antibiotics are widely used for preventing bacterial infections in humans and animals (Luo et al., 2011; Hong et al., 2013). Since the discovery of antibiotics, their global production and use have been increasing rapidly, causing some concern (Kasprzyk-Hordern et al., 2009). Antibiotics have different half-lives in the environment, and some of them have high persistence; therefore, they have been polluting the environment at an alarming rate (Petrie et al., 2015; Carvalho and Santos, 2016).

Abbreviations: $\mathrm{BC} / \mathrm{MnO} 2$, Biochar-supported manganese dioxide composite; BET, BrunnerÜEmmetÜTeller; DC, Doxycycline; FTIR, Fourier transform infrared spectroscopy; SEM, Scanning electron microscopy; TC, Tetracycline hydrochloride; TG, Thermogravimetric; XPS, X-ray photoelectron spectroscopy. 
Residues have been frequently detected in surface water and groundwater worldwide (Homem and Santos, 2011; Yu et al., 2016). Notably, long-term exposure to antibiotic residues at relatively low concentrations can induce antibiotic resistance genes (Ahmed et al., 2015; Huang et al., 2015; Hou et al., 2016; Sharma et al., 2016). Due to the exposure to sublethal concentrations of antibiotic residues, drug-resistant strains of pathogens have become the dominant strains, which have rapidly developed and inherited antibiotic resistance genes. Therefore, antibiotics are ineffective against the pathogens with the corresponding antibiotic resistance genes, rendering their infections in humans difficult to cure (Drury et al., 2013; Frieri et al., 2017; Medernach and Logan, 2018). The World Health Organization studied the exact size of the world's bacterial resistance status in 2014 and reported that the resistance of common bacteria to antibiotics has reached alarming levels, and in several countries, the main groups of antibiotics have failed to benefit half of the patients (Organization, 2014). In addition, antibiotics may adversely affect human health by interfering with endocrines (Huang et al., 2018). Therefore, aqueous solution containing antibiotics must be effectively treated before being discharged into the environment. Tetracyclines have become one of the most consumed antibiotics in the world at low prices and broad-spectrum antibacterial properties (Zhang et al., 2018). The tetracycline residue in original wastewater of pharmaceutical factories was reported in extremely high levels $\left(844-1077 \mathrm{mg} \cdot \mathrm{L}^{-1}\right)$, while that in treated wastewater still ranged from several to dozens of $\mathrm{mg} \cdot \mathrm{L}^{-1}$ (Li et al., 2008; Zhang et al., 2018). Therefore, two typical tetracyclines, namely tetracycline hydrochloride (TC) and doxycycline (DC), were selected as target pollutants.

The main methods of removing antibiotics from water are biodegradation (Zhang et al., 2017), hydrolysis (Sarmah et al., 2006), photodegradation (Lu et al., 2018), and adsorption (Zeng et al., 2018; Liu et al., 2019). Among them, the adsorption method, which is the most efficient, economical, and environmentally friendly, has been widely used in the treatment of aqueous solution containing antibiotics. Finding an effective adsorbent is the key to expanding the application of this technology to antibiotic aqueous solution treatment. Biochar seems to be a promising adsorption material in pollutant treatment technologies, owing to its porous structure, complex surface, abundance of raw material, and economic benefits (Tan et al., 2015, 2016b; Liang et al., 2017; Zhang et al., 2019b). However, there is room to further improve the adsorption capacity of original biochar (Cai et al., 2018, 2019; Zhang et al., 2019a).

Nanoparticles of manganese oxide have been widely reported as an effective adsorbent (Song et al., 2014). Nano-scale $\mathrm{MnO}_{\mathrm{x}}$ particles have a high specific surface area owing to their superior polycrystalline structure, as well as high adsorption performance (Wang et al., 2010; Xiao et al., 2010). However, nano-sized $\mathrm{MnO}_{\mathrm{x}}$ particles easily agglomerate, thus limiting their practical application as adsorbents (Tyson et al., 2011; Li et al., 2017). In this study, a simple, low-cost method of loading $\mathrm{MnO}_{\mathrm{x}}$ nanoparticles onto biochar was developed for preparing a new biochar composite that can be used to adsorb antibiotics in aqueous solution. This method not only solves the agglomeration problem, but also improves the effectiveness of the nano-metal oxide $\mathrm{MnO}_{\mathrm{x}}$ in aiding biochar for better pollutant removal.

The main objectives of this study included: (1) Preparation of a biochar-supported manganese dioxide composite; (2) Characterization of the prepared composite using scanning electron microscopy (SEM), Fourier transform infrared spectroscopy (FTIR), X-ray diffraction (XRD), and X-ray photoelectron spectroscopy (XPS); (3) Removal of TC and DC using the prepared composite under different experimental conditions; (4) Evaluation of the isotherms and kinetic laws of the adsorption process.

\section{MATERIALS AND METHODS}

\section{Material Preparation Preparation of Biochar}

Rice husk, which is a common agricultural waste, was used as the biomass raw material in the preparation of biochar. The rice husk collected from the farm was rinsed with ultrapure water and air dried. Subsequently, it was completely dried in an oven at $60^{\circ} \mathrm{C}$ and grounded to a powder form. The rice husk powder was placed in a quartz boat and then heated in a quartz tube furnace (SK-1200 ${ }^{\circ}$ C, Tianjin Zhonghuan Experimental Furnace Co., Ltd., Tianjin, China). Both ends of the quartz tube were sealed, and the hose was connected. $\mathrm{N}_{2}$ was passed through the furnace chamber at a flow rate of $400 \mathrm{~mL} \cdot \mathrm{min}^{-1}$ from one end, and an inert atmosphere was maintained during the pyrolysis process. The volatile products generated during the pyrolysis of biomass were collected from the other end. The temperature was programmed to increase to $500^{\circ} \mathrm{C}$ at a rate of $7^{\circ} \mathrm{C} \mathrm{min}^{-1}$ and was maintained at the peak temperature for $2 \mathrm{~h}$, which was the optimal preparation condition in preliminary study ( $\mathrm{Wu}$ et al., 2016). Finally, the chamber was cooled to room temperature $\left(25 \pm 1^{\circ} \mathrm{C}\right)$ to obtain rice husk biochar.

\section{Synthesis of Biochar-Supported Nano Manganese Dioxide Composite}

A $4 \mathrm{mmol} \cdot \mathrm{L}^{-1}$ manganese chloride solution was prepared and then purified under $\mathrm{N}_{2}\left(100 \mathrm{~mL} \cdot \mathrm{min}^{-1}\right)$ for $20 \mathrm{~min}$ to remove dissolved oxygen. One gram of the above-mentioned chaff biochar was added to $30 \mathrm{~mL}$ of a manganese chloride solution and stirred under $\mathrm{N}_{2}$ atmosphere $\left(100 \mathrm{~mL} \cdot \mathrm{min}^{-1}\right)$ for $1 \mathrm{~h}$ to form a biochar- $\mathrm{Mn}^{2+}$ mixture. This mixture was added dropwise to $20 \mathrm{~mL}$ of a solution containing potassium permanganate and sodium hydroxide while stirring at $250 \mathrm{r}$. $\min ^{-1}$ using a magnetic stirrer. The stirring was continued for $20 \mathrm{~min}$ to ensure a complete reaction. After aging for $24 \mathrm{~h}$ at room temperature $\left(25 \pm 1^{\circ} \mathrm{C}\right)$, the mixture was washed several times with ultrapure water until the $\mathrm{pH}$ was neutral. Finally, it was completely dried in an oven at $80^{\circ} \mathrm{C}$. After grinding, it was made to pass through a 100 -mesh sieve to obtain a biochar-supported nano manganese dioxide composite $\left(\mathrm{BC} / \mathrm{MnO}_{2}\right)$.

\section{Characterization Methods}

The microstructure and morphology of the composites were studied using a QUANTA 250 FE-SEM (FEI, United States). 
XRD patterns were acquired using a Bruker D8-Advance X-ray diffractometer (Bruker, Germany). The surface elements were determined using an ESCALAB 250Xi X-ray photoelectron spectrometer (Thermo Fisher Scientific, United States). A Fourier transform infrared spectrometer was used (NICOLET 5700; Thermo Nicolet Corporation, United States). The thermogravimetric (TG) curve of the material was measured in $\mathrm{N}_{2}$ atmosphere by varying the temperature from room temperature $\left(25 \pm 1^{\circ} \mathrm{C}\right.$ ) to $1000^{\circ} \mathrm{C}$ (flux rate: $100 \mathrm{~mL} \cdot \mathrm{min}^{-1}$; heating rate: $10^{\circ} \mathrm{C} \cdot \mathrm{min}^{-1}$ ) using an SDT Q600 thermal analyzer (TA, United States). The Brunner-Emmet-Teller (BET) specific surface area of the material was measured using a Micromeritics 3Flex analyzer (Micromeritics Instrument Corporation, United States).

\section{Adsorption Experiments}

\section{Effect of Adsorbent Dose on Adsorption}

Various amounts of $\mathrm{BC} / \mathrm{MnO}_{2}(10,20,40,80,100$, and $150 \mathrm{mg})$ were added to $25 \mathrm{~mL}$ of $5 \mathrm{mg} \cdot \mathrm{L}^{-1} \mathrm{TC}$ and $\mathrm{DC}$ solutions $(\mathrm{pH}=6.0)$. The resulting mixture was sealed using a plastic wrap and rotated in a constant-temperature shaker at a speed of $170 \mathrm{r} \cdot \mathrm{min}^{-1}$. The reaction temperature was set to $25^{\circ} \mathrm{C}$, and the mixture was shaken for $24 \mathrm{~h}$. Finally, a sample was taken for measurement.

\section{Effect of $\mathrm{pH}$ on Adsorption}

TC and DC solutions (both the concentrations were $5 \mathrm{mg}$. $\mathrm{L}^{-1}$ ) with a $\mathrm{pH}$ value ranging from 2.0 to 10.0 were prepared. Subsequently, $0.1 \mathrm{~g}$ of $\mathrm{BC} / \mathrm{MnO}_{2}$ was added to $25 \mathrm{~mL}$ of the above solution. The mixture was sealed using a plastic wrap and rotated in the constant-temperature shaker at a speed of $170 \mathrm{r} \cdot \mathrm{min}^{-1}$. The reaction temperature was set to $25^{\circ} \mathrm{C}$, and the mixture was shaken for $24 \mathrm{~h}$. Finally, a sample was taken for measurement.

\section{Effect of Initial Antibiotics Concentration and Adsorption Temperature}

TC and DC solutions were prepared at a concentration ranging from 5 to $100 \mathrm{mg} \cdot \mathrm{L}^{-1}(\mathrm{pH}=6.0)$. At reaction temperatures of 25,35 , and $45^{\circ} \mathrm{C}, 0.1 \mathrm{~g}$ of $\mathrm{BC} / \mathrm{MnO}_{2}$ was taken and added to $25 \mathrm{~mL}$ of the above solutions. The mixture was then sealed using a plastic wrap and rotated in the constant-temperature shaker at a speed of $170 \mathrm{r} \cdot \mathrm{min}^{-1}$. The mixture was shaken for $24 \mathrm{~h}$ and sampled for measurement.

\section{Effect of Reaction Time on Adsorption}

The kinetic test interval was from 0 to $1440 \mathrm{~min}$. $\mathrm{BC} / \mathrm{MnO}_{2}$ $(0.1 \mathrm{~g})$ was added to $25 \mathrm{~mL}$ of TC and DC solutions with a concentration of $50 \mathrm{mg} \cdot \mathrm{L}^{-1}$, with $\mathrm{pH}=6.0$. The mixture was

TABLE 1 | Characteristics of $\mathrm{BC} / \mathrm{MnO}_{2}$.

\begin{tabular}{lccccccc}
\hline & $\begin{array}{c}\text { BET surface } \\
\text { area }\left(\mathbf{m}^{\mathbf{2}} \mathbf{g}^{-1}\right)\end{array}$ & $\begin{array}{c}\text { Pore volume } \\
\left(\mathbf{c m}^{\mathbf{3}} \mathbf{g}^{-\mathbf{1}}\right)\end{array}$ & $\begin{array}{c}\text { Pore size } \\
(\mathbf{n m})\end{array}$ & \multicolumn{2}{c}{$\begin{array}{c}\text { Bulk elemental } \\
\text { composition (\%) }\end{array}$} \\
\cline { 6 - 8 } & & & & & $\mathbf{C}$ & $\mathbf{0}$ & $\mathbf{M n}$ \\
\hline $\mathrm{BC}$ & 6.67 & 0.006 & 3.66 & 73.64 & 23.66 & - \\
$\mathrm{BC} / \mathrm{MnO}_{2}$ & 64.32 & 0.24 & 13.10 & 58.76 & 31.89 & 7.13
\end{tabular}

sealed using a plastic wrap, and the reaction temperature was set to $25^{\circ} \mathrm{C}$. It was then shaken in the constant temperature shaker at a speed of $170 \mathrm{r} \cdot \mathrm{min}^{-1}$. Samples were taken for measurement at the corresponding time.

\section{Detection Method}

The residual antibiotics concentration in the solution was determined by UV spectrophotometry (Ma et al., 2018). The solutions were separated and filtered, and the residual concentration of TC and DC in the liquid was detected by UV spectrophotometer (UV-2550, Shimadzu, Japan) at $357 \mathrm{~nm}$ (Jing et al., 2014) and $346 \mathrm{~nm}$ (Xiong et al., 2019), respectively.

\section{RESULTS AND DISCUSSION}

\section{Characterization}

Table 1 lists the physical and chemical characteristics of $\mathrm{BC} / \mathrm{MnO}_{2}$. The elemental analysis shows that compared with the
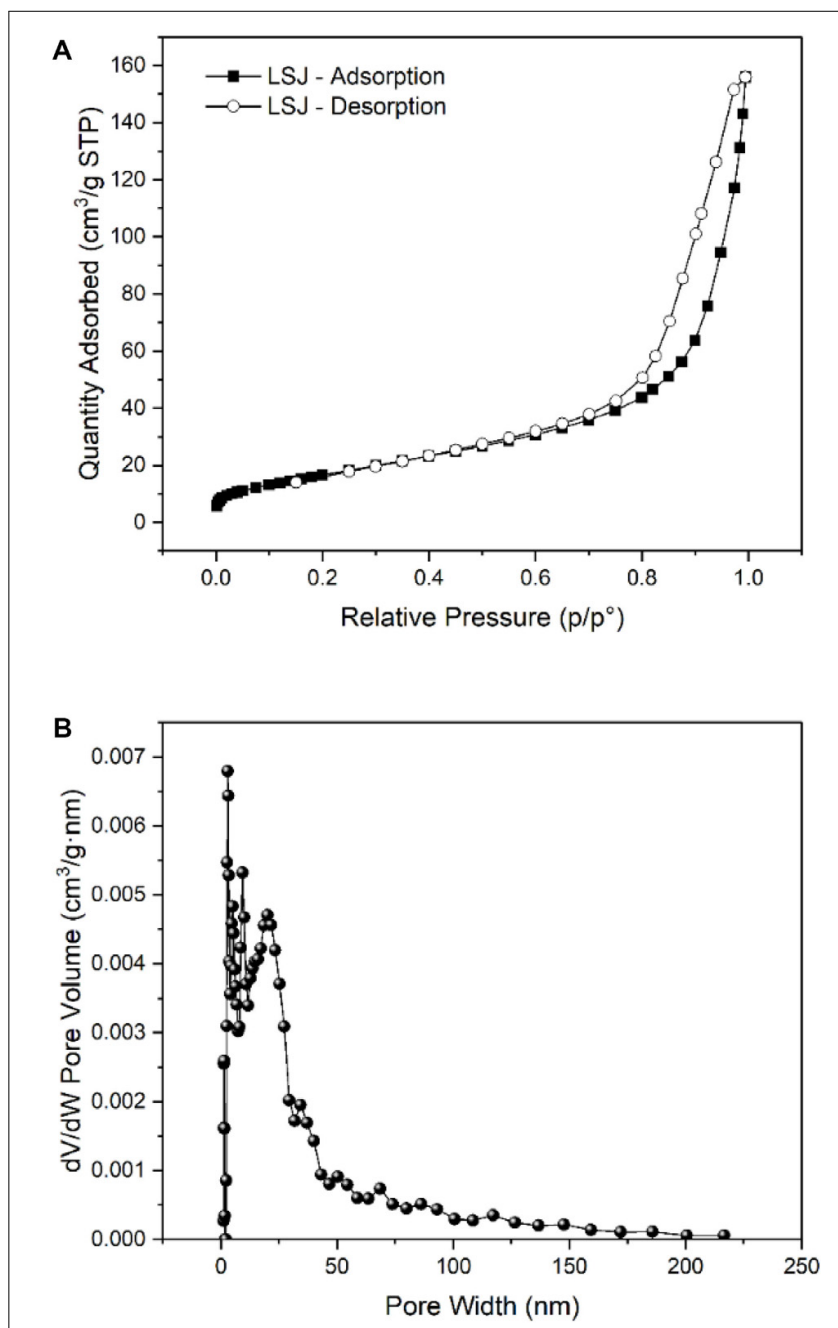

FIGURE 1 | (A) Nitrogen adsorption-desorption isotherms, and (B) pore size distribution of $\mathrm{BC} / \mathrm{MnO}_{2}$. 
original biochar, manganese appears on the surface of $\mathrm{BC} / \mathrm{MnO}_{2}$ owing to the introduction of $\mathrm{MnO}_{2}$, and the carbon content of the biochar is decreased, whereas the oxygen content is increased. Compared with the original biochar $\left(0.006 \mathrm{~cm}^{3} \cdot \mathrm{g}^{-1}\right), \mathrm{BC} / \mathrm{MnO}_{2}$ $\left(0.24 \mathrm{~cm}^{3} \cdot \mathrm{g}^{-1}\right)$ has a significantly larger total pore volume. In addition, the specific surface area of the biochar is increased from 6.67 to $64.32 \mathrm{~m}^{2} \cdot \mathrm{g}^{-1}$, indicating an improvement in its pore structure.

The $\mathrm{N}_{2}$ adsorption-desorption isotherm and pore size distribution of $\mathrm{BC} / \mathrm{MnO}_{2}$ were measured at $77.3 \mathrm{~K}$. Figure 1 shows the results. According to the IUPAC classification, the shape of the isotherm is IV, indicating that $\mathrm{BC} / \mathrm{MnO}_{2}$ has a flat slit, wedge structure (Saiah et al., 2009). The pore size distribution of $\mathrm{BC} / \mathrm{MnO}_{2}$ is mainly in the range of $0-50 \mathrm{~nm}$, and the average pore size is $13.10 \mathrm{~nm}$. The increased specific surface area and total pore volume were beneficial for improving the adsorption performance of $\mathrm{BC} / \mathrm{MnO}_{2}$.

Figure 2 shows the SEM morphologies of $\mathrm{BC} / \mathrm{MnO}_{2}$. $\mathrm{BC} / \mathrm{MnO}_{2}$ exhibits an irregular surface with micropores of different shapes and sizes, and a large number of particles are uniformly precipitated on the surface of biochar, indicating the successful coating of the $\mathrm{MnO}_{2}$ nanoparticles on the biochar surface. The TEM image (Figure 3) shows that $\mathrm{MnO}_{2}$ is successfully loaded on the biochar and that $\mathrm{MnO}_{2}$ nano-flakes are embedded in the biochar matrix.

Figure $4 \mathrm{~A}$ shows the $\mathrm{XRD}$ pattern of $\mathrm{BC} / \mathrm{MnO}_{2}$. The characteristic peak of $\mathrm{BC} / \mathrm{MnO}_{2}$ at $2 \theta=30.082^{\circ}$ indicates the presence of $\mathrm{MnO}_{2}$ on the biochar surface. Figure 4B shows the

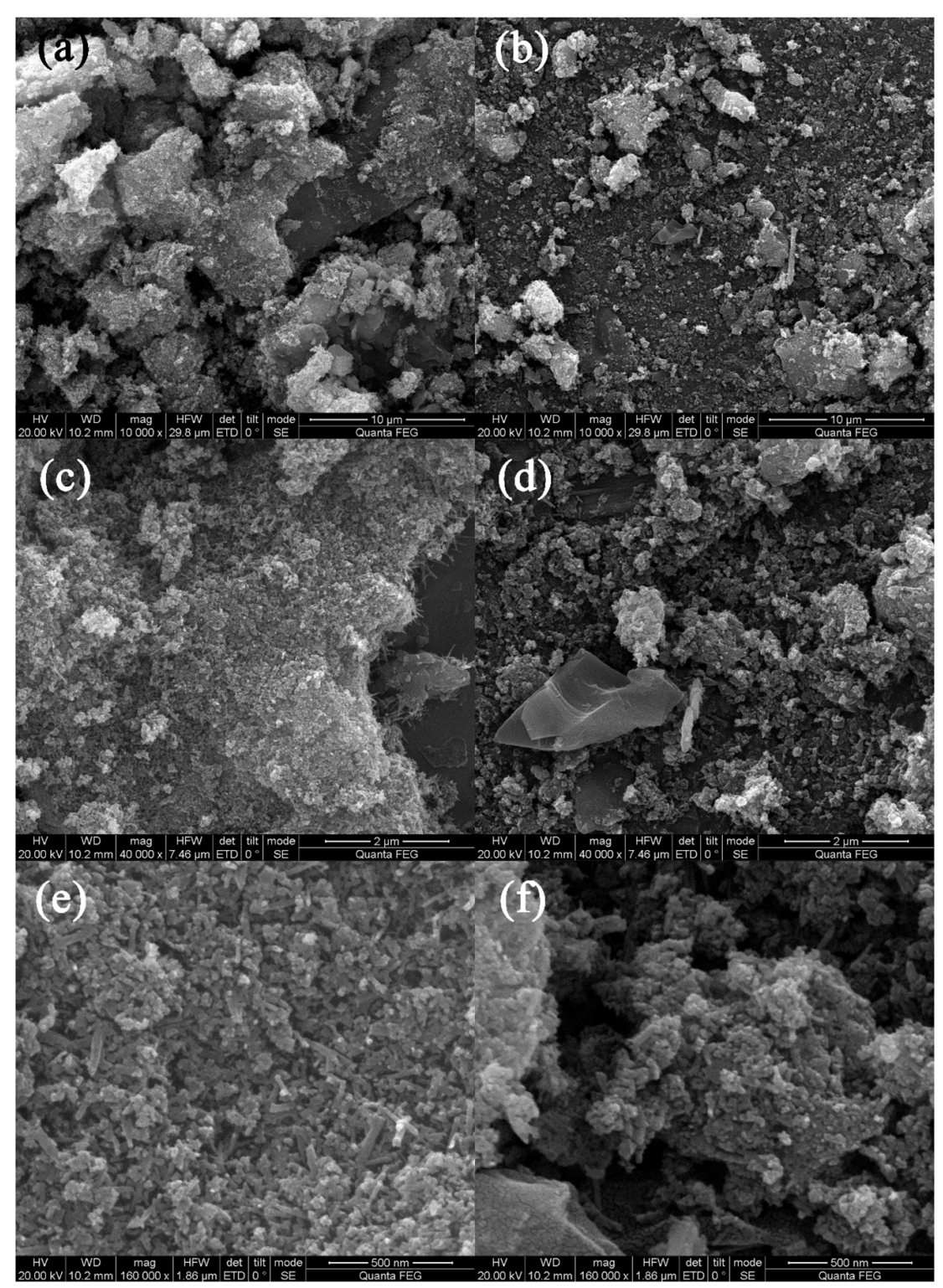

FIGURE 2 | SEM images of $\mathrm{BC} / \mathrm{MnO}_{2}$ under different magnification: (a,b) 10000×, (c,d) 40000×, and (e,f) $160000 \times$. 


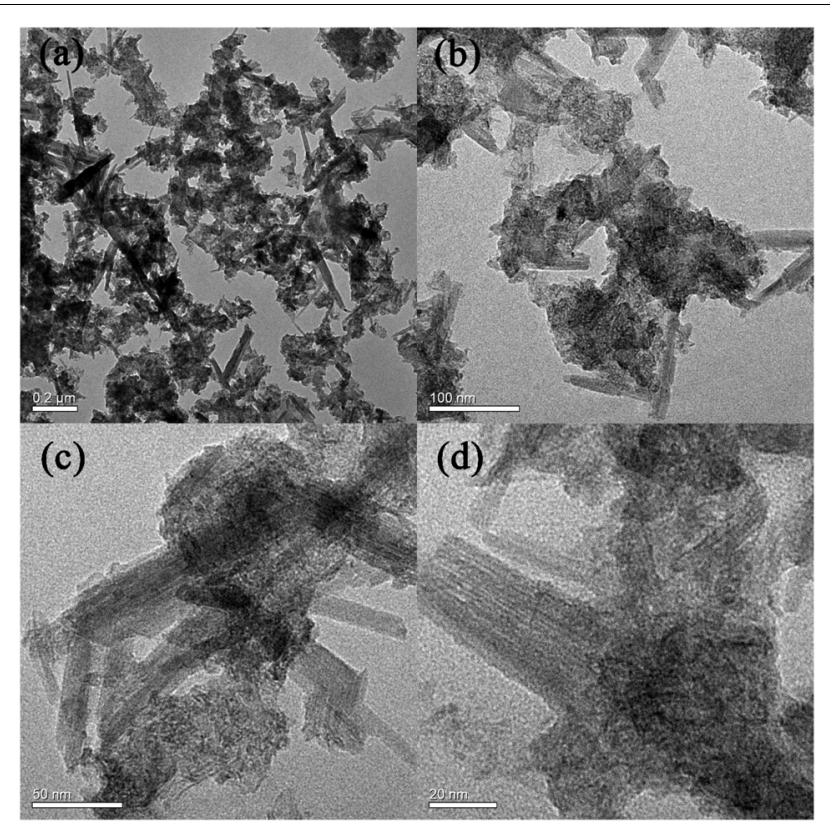

FIGURE 3 | TEM images of $\mathrm{BC} / \mathrm{MnO}_{2}$ under different magnification: (a) $0.2 \mu \mathrm{m}$, (b) $100 \mathrm{~nm}$, (c) $50 \mathrm{~nm}$, and (d) $20 \mathrm{~nm}$.

TG analysis results. The weight loss of approximately $10 \%$ in the temperature range of $30-120^{\circ} \mathrm{C}$ is mainly due to the dehydration process (Shete et al., 2015). When the temperature gradually increases from 120 to $500^{\circ} \mathrm{C}$, the weight loss of the biochar decreases by only approximately $20 \%$. The weight loss at $800^{\circ} \mathrm{C}$ is approximately $30 \%$. This shows that $\mathrm{BC} / \mathrm{MnO}_{2}$ has higher thermal stability than the original biochar.

The chemical composition of the $\mathrm{BC} / \mathrm{MnO}_{2}$ surface was further studied by conducting an XPS analysis (Figure 5). The characteristic Mn2p peak (Figure 5A) can be divided into three peaks by Gaussian fitting. The peak position of $\mathrm{Mn}^{4+}$ can be observed at $644.04 \mathrm{eV}$ (Yin et al., 2015). The peaks at 642.05 and $653.78 \mathrm{eV}$ belong to $\mathrm{Mn}_{2} \mathrm{p}_{3 / 2}$ and $\mathrm{Mn} 2 \mathrm{p}_{1 / 2}$, respectively, with an energy interval of $11.73 \mathrm{eV}$, which is consistent with the results reported for $\mathrm{MnO}_{2}$ (Xie et al., 2017; Li et al., 2018). The characteristic peaks of the XPS spectrum of O1s (Figure 5B) are 533.20, 531.55, 530.54, and $529.56 \mathrm{eV}$, indicating the presence of $\mathrm{C}-\mathrm{O}, \mathrm{C}=\mathrm{O}, \mathrm{O}-\mathrm{H}$, and $\mathrm{Mn}-\mathrm{O}$, respectively (Yu et al., 2007; Han et al., 2013; Zhang et al., 2014; Bose and Biju, 2015). These functional groups can serve as binding sites for the adsorption of antibiotics. The above results once again demonstrate the successful loading of the $\mathrm{MnO}_{2}$ nanoparticles on the surface of biochar.

\section{Comparison of the Performance of Pristine Biochar and $\mathrm{BC} / \mathrm{MnO}_{2}$}

The adsorption ability of pristine biochar and $\mathrm{BC} / \mathrm{MnO}_{2}$ for $\mathrm{TC}$ and $\mathrm{DC}$ were compared at initial antibiotic concentrations range from 5 to $100 \mathrm{mg} \cdot \mathrm{L}^{-1}$. As can be seen from Figure 6, after the coating of $\mathrm{MnO}_{2}$, the adsorption ability of $\mathrm{BC} / \mathrm{MnO}_{2}$ for both TC and DC were significantly higher than that of pristine biochar. These results suggested that the loading of $\mathrm{MnO}_{2}$ was an effective way to improve the adsorption ability of biochar for TC and DC. The increased specific surface area and total pore volume, and the loading of $\mathrm{MnO}_{2}$ served as bonding sites might be account for the enhanced adsorption performance of $\mathrm{BC} / \mathrm{MnO}_{2}$.

\section{Effect of Adsorbent Dose}

Figure 7 shows the effect of $\mathrm{BC} / \mathrm{MnO}_{2}$ dose on the adsorption of TC and DC. With the increase in the $\mathrm{BC} / \mathrm{MnO}_{2}$ dose, the relative adsorption amounts of TC and DC gradually decrease. This is mainly because an excessive dose leads to excess adsorption sites and reduces the adsorbent utilization rate (Wu et al., 2014). With the increase in the adsorbent dose, the removal rates of TC and DC increase, mainly because of the increase in the number of adsorption sites. However, there was no significant difference between the adsorption ability of $\mathrm{BC} / \mathrm{MnO}_{2}$ for $\mathrm{TC}$ and $\mathrm{DC}$, with slightly higher performance for DC. Similar results could be found in the later adsorption experiments.

As can be seen from Figure 7, when the dose of $\mathrm{BC} / \mathrm{MnO}_{2}$ is $0.1 \mathrm{~g}$, the effect of the composite material on antibiotic
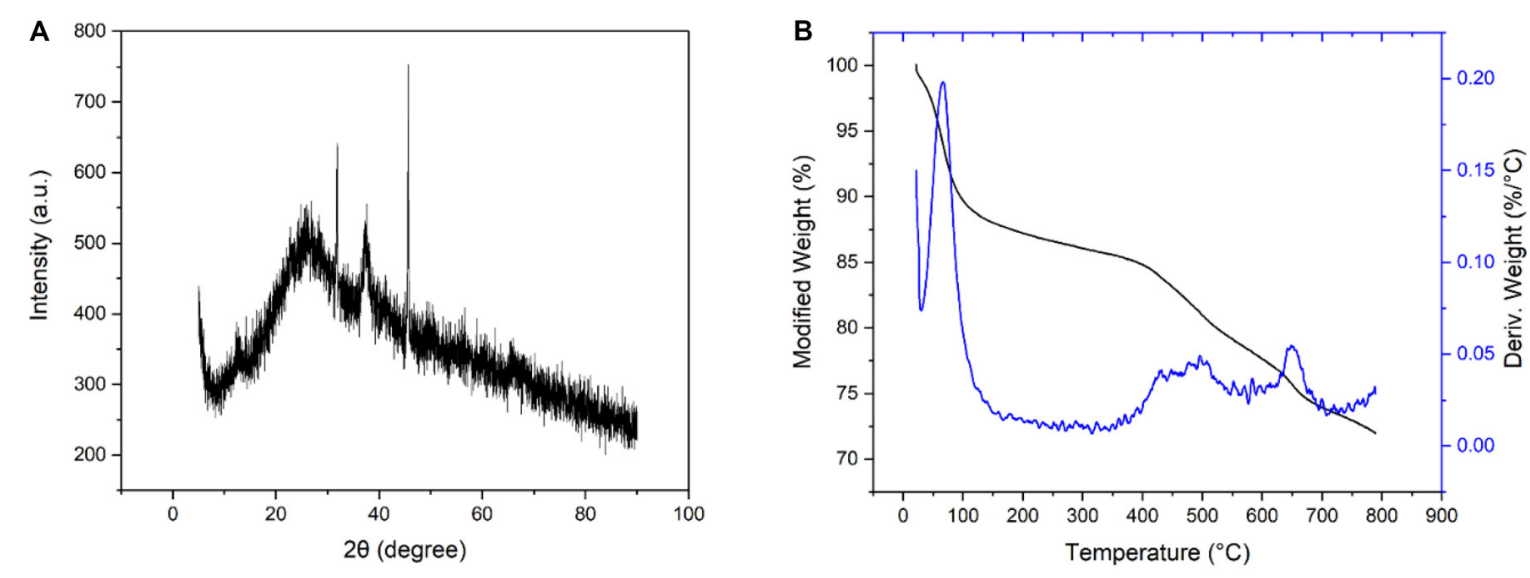

FIGURE 4 | (A) XRD spectrum of $\mathrm{BC} / \mathrm{MnO}_{2}$, (B) TG curves of $\mathrm{BC} / \mathrm{MnO}_{2}$. 

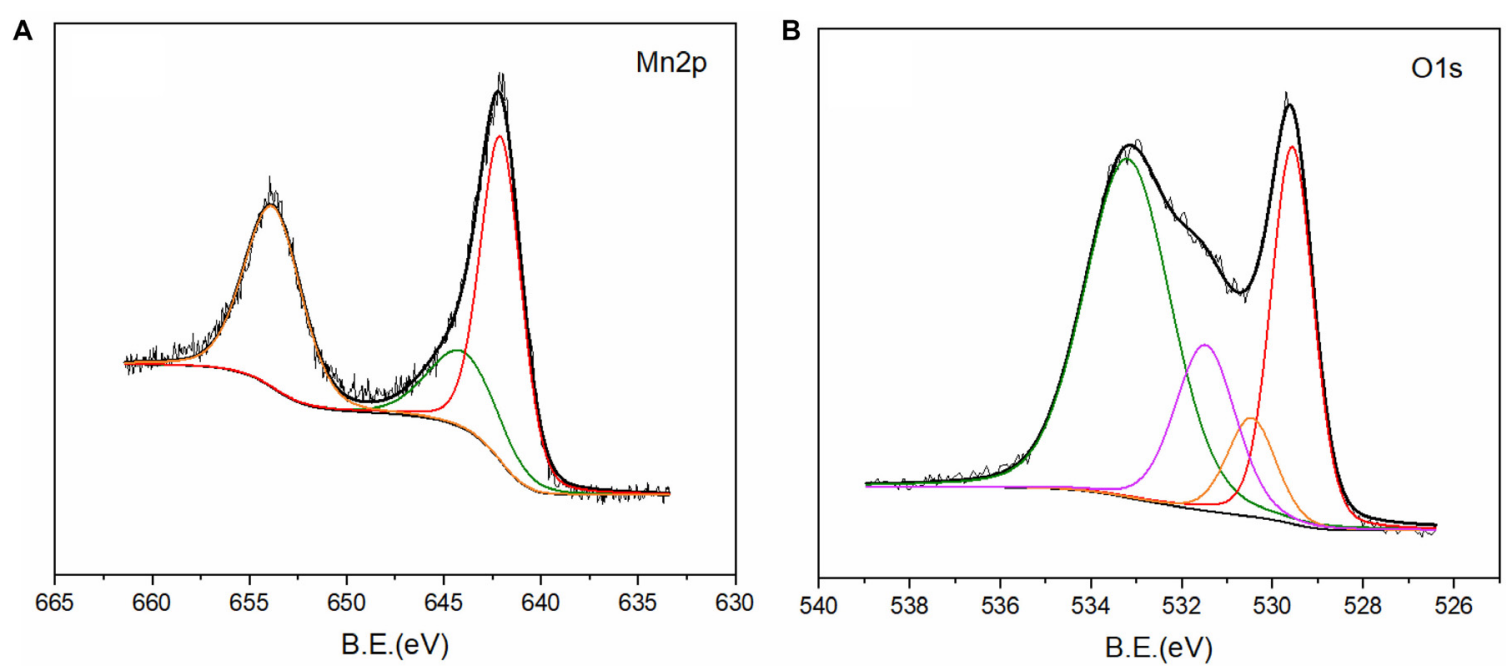

FIGURE 5 |XPS spectra of $\mathrm{BC} / \mathrm{MnO}_{2}:$ (A) Mn2p and (B) O1s.

contaminants is very obvious, in which the removal rate of doxycycline reaches $90 \%$, and the removal rate of tetracycline hydrochloride is nearly $95 \%$. This is conducive to the comparative observation of experimental effects. Therefore, according to the concentration of antibiotic contaminants and the results of preliminary experiments, we chose $0.1 \mathrm{~g}$ as the dose of adsorbent in other parts of the experiment.

\section{Effect of pH}

Figure 8 shows the effect of initial $\mathrm{pH}$ on the adsorption of $\mathrm{TC}$ and $\mathrm{DC}$ by $\mathrm{BC} / \mathrm{MnO}_{2}$. According to the result obtained by Figure 8B, the zero-potential point of $\mathrm{BC} / \mathrm{MnO}_{2}$ is around 3.2. At low $\mathrm{pH}$, TC and DC mainly exist in cationic form, and the surface of the biochar composite is positively charged (Figure 8B).

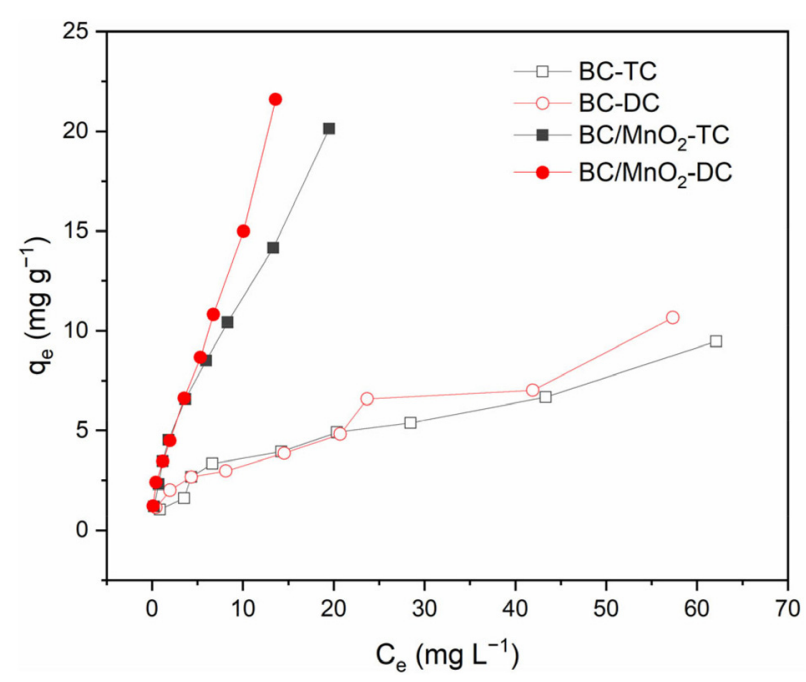

FIGURE 6 | The adsorption ability of biochar and $\mathrm{BC} / \mathrm{MnO}_{2}$ for $\mathrm{TC}$ and $\mathrm{DC}$.
Therefore, under this condition, electrostatic repulsion may occur between them. Similarly, at high $\mathrm{pH}$, anionic antibiotics are repelled by the negatively charged biochar surface (Figure 8B), inhibiting TC and DC adsorption (Wang et al., 2016). However, the removal rate did not change significantly across the tested $\mathrm{pH}$ range, suggesting that the electrostatic interactions were not the main mechanism whereby biochar composites adsorb TC and DC. Other forces may have formed between the antibiotics and the carboxyl or hydroxyl groups on the surface of the new biochar composite, including $\pi-\pi$ interaction and hydrogen bonding (Zheng et al., 2013; Zeng et al., 2019; Ye et al., 2020). In addition, part of TC and DC could be adsorbed by $\mathrm{MnO}_{2}$ particles on biochar surface (Mahamallik et al., 2015). Overall, the effect of $\mathrm{pH}$ on the adsorption of TC and DC by the new biochar composite is not significant.

\section{Adsorption Isotherms}

The Langmuir, Freundlich and Temkin models were used to study the adsorption equilibrium isotherms and fit the experimental data. The adsorption models are expressed as follows (Zhang et al., 2019a):

$$
\frac{C_{\mathrm{e}}}{q_{\mathrm{e}}}=\frac{C_{\mathrm{e}}}{q_{\max }}+\frac{1}{q_{\max } K_{\mathrm{L}}}
$$

Here, $q_{\mathrm{e}}$ is the adsorption amount $\left(\mathrm{mg} \cdot \mathrm{g}^{-1}\right) ; C_{\mathrm{e}}$ is the concentration at the end of the adsorption reaction $\left(\mathrm{mg} \cdot \mathrm{L}^{-1}\right)$; $q_{\max }$ is the maximum adsorption amount $\left(\mathrm{mg} \cdot \mathrm{g}^{-1}\right)$; and $K_{\mathrm{L}}$ is the Langmuir constant related to adsorption $\left(\mathrm{L} \cdot \mathrm{mg}^{-1}\right)$, which is used to indicate whether the adsorption equilibrium is favorable $\left(0<K_{\mathrm{L}}<1\right)$ or unfavorable $\left(K_{\mathrm{L}}>1\right)$.

$$
\ln q_{\mathrm{e}}=\ln K_{\mathrm{F}}+\frac{1}{n} \ln C_{\mathrm{e}}
$$

Here, $q_{\mathrm{e}}$ is the adsorption amount $\left(\mathrm{mg} \cdot \mathrm{g}^{-1}\right) ; C_{\mathrm{e}}$ is the concentration at the end of the adsorption reaction $\left(\mathrm{mg} \cdot \mathrm{L}^{-1}\right)$; 

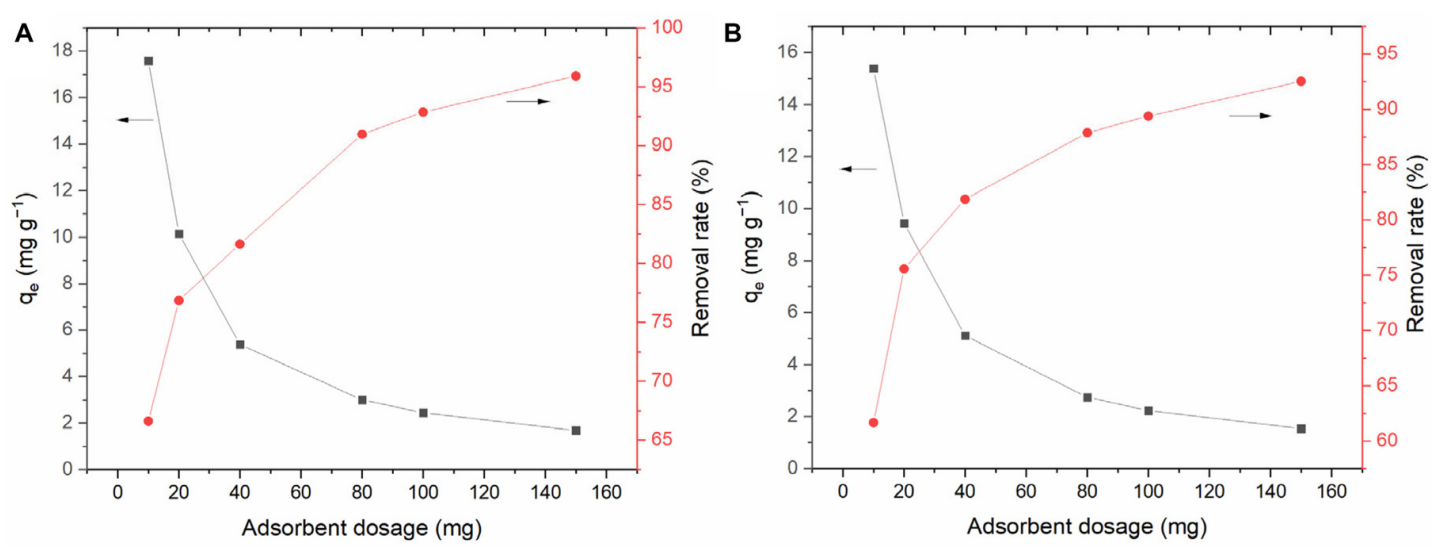

FIGURE 7 | Effect of adsorbent $\left(\mathrm{BC} / \mathrm{MnO}_{2}\right)$ dose on adsorption efficiency: (A) tetracycline hydrochloride, (B) doxycycline.
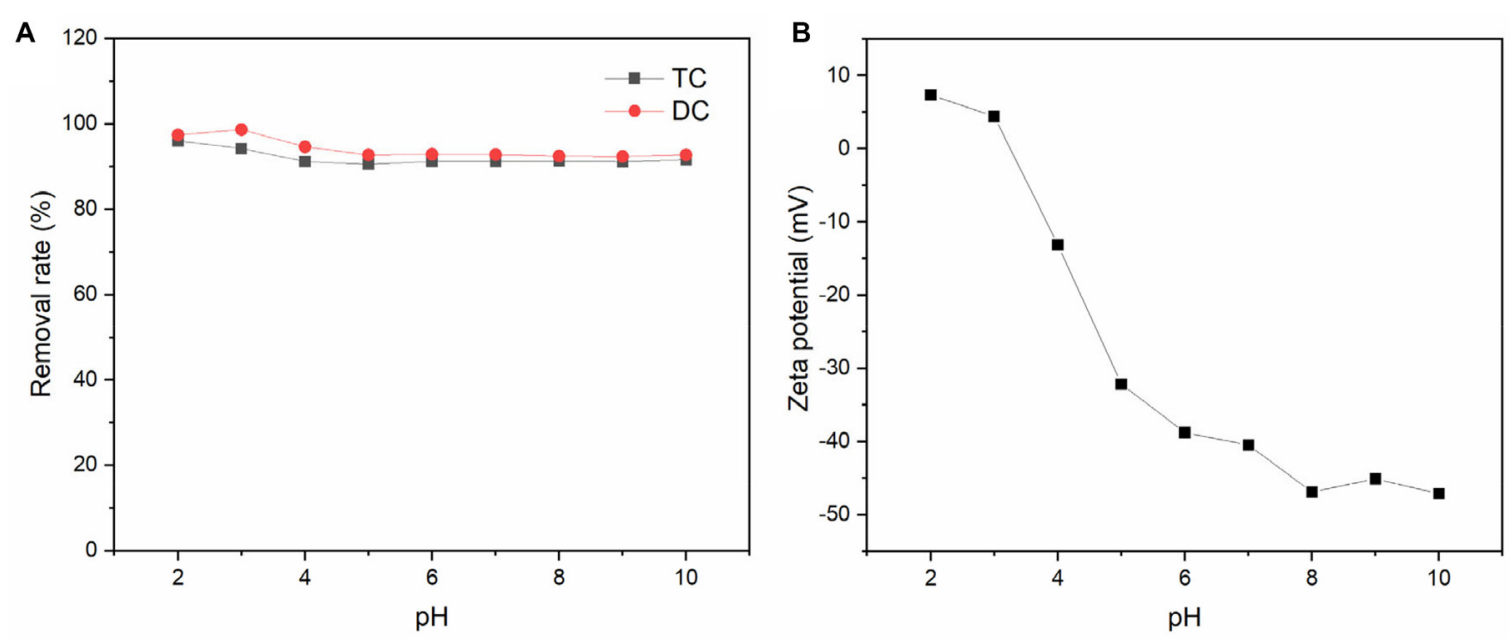

FIGURE 8 | (A) Effect of solution $\mathrm{pH}$ on the adsorption of $\mathrm{TC}$ and $\mathrm{DC}$ by $\mathrm{BC} / \mathrm{MnO}_{2}$; (B) the zeta potential of $\mathrm{BC} / \mathrm{MnO}_{2}$ at different $\mathrm{pH}$.

$K_{\mathrm{F}}$ is the Freundlich constant $\left(\mathrm{L} \cdot \mathrm{mg}^{-1}\right)$ representing the adsorption capacity; and $n$ is the Freundlich constant representing the adsorption strength.

$$
q_{\mathrm{e}}=B_{\mathrm{T}} \ln K_{\mathrm{T}}+B_{\mathrm{T}} \ln C_{\mathrm{e}}
$$

Here, $q_{\mathrm{e}}$ is the adsorption amount $\left(\mathrm{mg} \cdot \mathrm{g}^{-1}\right), C_{\mathrm{e}}$ is the concentration at the end of the adsorption reaction $\left(\mathrm{mg} \cdot \mathrm{L}^{-1}\right)$. $B_{T}=R T / b_{T}$ and $b_{T}\left(\mathrm{~J} \cdot \mathrm{mol}^{-1}\right)$ is the Temkin constant, $R$ is the universal gas constant $\left(8.314 \mathrm{~J} \cdot \mathrm{mol}^{-1} \cdot \mathrm{K}^{-1}\right)$ and $T$ is the temperature $(\mathrm{K}) ; K_{T}\left(\mathrm{~L} \cdot \mathrm{mg}^{-1}\right)$ is the maximum binding energy constant.

In the Langmuir model, it is assumed that a single molecular layer is formed when adsorption occurs and that the adsorbed molecules do not interact. Figure 9 shows the relationship between $C_{\mathrm{e}} / q_{\mathrm{e}}$ and $C_{\mathrm{e}}$. Table 2 lists the values of the related parameters. Temkin isotherm is based on an assumption that the indirect interactions are existed between adsorbate molecules, and the heat of adsorption of molecules will decrease linearly with surface coverage (Zhang et al., 2019a).
At the three temperatures studied, the adsorption data show a poor correlation with the Langmuir and Temkin model, whereas they show a strong correlation with the Freundlich model, indicating that the adsorption of TC and $\mathrm{DC}$ by $\mathrm{BC} / \mathrm{MnO}_{2}$ better conforms to the Freundlich adsorption model (Wu et al., 2014). The Freundlich adsorption model is an empirical equation where it is assumed that adsorption occurs on a heterogeneous surface and that the adsorption capacity is related to the equilibrium concentration (Cui et al., 2015). In Table 2, the values of $1 / n$ are less than 1, indicating that TC and DC easily get adsorbed by $\mathrm{BC} / \mathrm{MnO}_{2}$ at these temperatures.

Thermodynamic analysis was further applied to study thee adsorption process and mechanisms. The Gibbs free energy $\Delta G^{\circ}$, enthalpy $\Delta H^{\circ}$, entropy $\Delta S^{\circ}$ were calculated using the following equations (Tan et al., 2016a):

$$
\begin{gathered}
\Delta G^{0}=-R T K^{0} \\
\ln k^{0}=-\frac{\Delta H^{0}}{R T}+\frac{\Delta S^{0}}{R}
\end{gathered}
$$



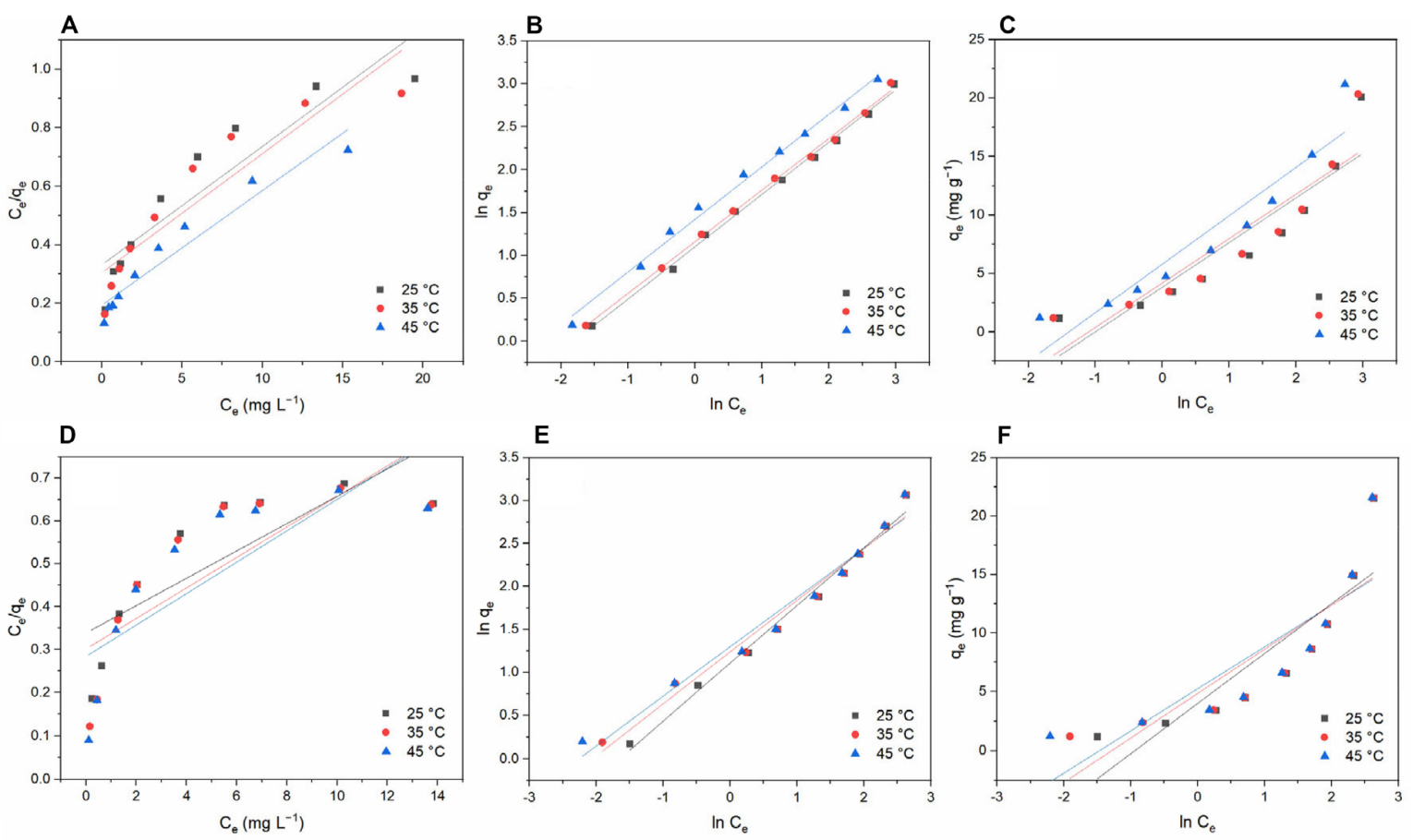

FIGURE 9 | Equilibrium isotherms for tetracycline hydrochloride and doxycycline adsorbed by $\mathrm{BC} / \mathrm{MnO}_{2}$ at different temperatures: (A) Langmuir model for TC; (B) Freundlich model for TC; (C) Temkin model for TC; (D) Langmuir model for DC; (E) Freundlich model for DC; and (F) Temkin model for DC.

Here, $R$ is the gas constant $8.314 \mathrm{~J} \cdot \mathrm{mol}^{-1} \cdot \mathrm{K}^{-1}, T(\mathrm{~K})$ is the adsorption temperature; $K^{0}$ could be calculated by plotting $\ln \left(q_{\mathrm{e}} / c_{\mathrm{e}}\right)$ versus $c_{\mathrm{e}}$ and extrapolating $c_{\mathrm{e}}$ to zero.

TABLE 2 | Model parameters and the corresponding correlation coefficients of isotherm models.

\begin{tabular}{|c|c|c|c|c|c|}
\hline \multirow[t]{2}{*}{ Contaminants } & \multirow[t]{2}{*}{ Isotherms } & \multirow[t]{2}{*}{ Parameters } & \multicolumn{3}{|c|}{ Temperature (K) } \\
\hline & & & 298 & 303 & 318 \\
\hline \multirow[t]{10}{*}{ TC } & \multirow[t]{3}{*}{ Langmuir } & $q_{\max }\left(\mathrm{mg} \cdot \mathrm{g}^{-1}\right)$ & 24.69 & 24.55 & 25.50 \\
\hline & & $K_{\mathrm{L}}\left(\mathrm{L} \cdot \mathrm{mg}^{-1}\right)$ & 0.12 & 0.13 & 0.20 \\
\hline & & $R^{2}$ & 0.854 & 0.854 & 0.935 \\
\hline & \multirow[t]{3}{*}{ Freundlich } & $1 / n$ & 0.61 & 0.60 & 0.61 \\
\hline & & $K_{\mathrm{F}}\left(\mathrm{L} \cdot \mathrm{mg}^{-1}\right)$ & 3.01 & 3.19 & 4.14 \\
\hline & & $R^{2}$ & 0.997 & 0.997 & 0.993 \\
\hline & \multirow[t]{4}{*}{ Temkin } & $K_{\mathrm{t}}(\mathrm{L} / \mathrm{mg})$ & 2.74 & 3.02 & 4.06 \\
\hline & & $B_{t}$ & 3.81 & 3.79 & 4.14 \\
\hline & & $R^{2}$ & 0.810 & 0.809 & 0.848 \\
\hline & & $b_{\mathrm{t}}(\mathrm{J} / \mathrm{mol})$ & 650.28 & 675.65 & 638.61 \\
\hline \multirow[t]{10}{*}{ DC } & \multirow[t]{3}{*}{ Langmuir } & $q_{\max }\left(\mathrm{mg} \cdot \mathrm{g}^{-1}\right)$ & 27.29 & 28.10 & 31.34 \\
\hline & & $K_{\mathrm{L}}\left(\mathrm{L} \cdot \mathrm{mg}^{-1}\right)$ & 0.13 & 0.12 & 0.09 \\
\hline & & $R^{2}$ & 0.649 & 0.640 & 0.662 \\
\hline & \multirow[t]{3}{*}{ Freundlich } & $1 / n$ & 0.57 & 0.61 & 0.67 \\
\hline & & $K_{\mathrm{F}}\left(\mathrm{L} \cdot \mathrm{mg}^{-1}\right)$ & 3.66 & 3.45 & 3.03 \\
\hline & & $R^{2}$ & 0.966 & 0.970 & 0.986 \\
\hline & \multirow[t]{4}{*}{ Temkin } & $K_{\mathrm{t}}\left(\mathrm{L} \mathrm{mg}^{-1}\right)$ & 4.34 & 3.62 & 2.56 \\
\hline & & $B_{\mathrm{t}}$ & 3.57 & 3.77 & 4.25 \\
\hline & & $R^{2}$ & 0.675 & 0.693 & 0.733 \\
\hline & & $b_{t}\left(\mathrm{~J} \mathrm{~mol}^{-1}\right)$ & 694.00 & 679.23 & 622.08 \\
\hline
\end{tabular}

The calculated thermodynamic data of $\Delta G^{\circ}, \Delta H^{\circ}$, and $\Delta S^{\circ}$ are given in Table 3. The negative value of $\Delta G^{\circ}$ at three temperatures indicated the feasibility and spontaneous reaction of TC and DC adsorption onto $\mathrm{BC} / \mathrm{MnO}_{2}$. In addition, the $\Delta G^{\circ}$ values of TC and DC decreased from -2.80 to $-4.25 \mathrm{~kJ}$. $\mathrm{mol}^{-1}$ and from -3.33 to $-4.25 \mathrm{~kJ} \cdot \mathrm{mol}^{-1}$ with the increase of temperature, respectively, indicating that higher temperature was more favorable for adsorption. The positive $\Delta H^{\circ}$ value indicated the endothermic property of the adsorption process. The positive value of $\Delta S^{\circ}$ might be due to the increase of randomness of solid and solution interface in the process of adsorption (Tan et al., 2016a).

\section{Adsorption Kinetics}

To determine the adsorption equilibrium time of $\mathrm{BC} / \mathrm{MnO}_{2}$ for TC and DC and to study the kinetics of the adsorption process, the effect of time on the adsorption of TC and DC by $\mathrm{BC} / \mathrm{MnO}_{2}$ was analyzed. Two conventional kinetic models

TABLE 3 | Thermodynamic parameters for TC and DC adsorption by $\mathrm{BC} / \mathrm{MnO}_{2}$.

\begin{tabular}{|c|c|c|c|c|c|}
\hline Contaminants & $\mathrm{T}\left({ }^{\circ} \mathrm{C}\right)$ & $\Delta G^{\circ}\left(\mathrm{kJ} \mathrm{mol}^{-1}\right.$ & $\Delta H^{\circ}(\mathrm{kJ} \mathrm{mol}-1$ & $\Delta S^{\circ}\left(\mathrm{J} \mathrm{mol}^{-1} \mathrm{~K}\right)$ & $R^{2}$ \\
\hline \multirow[t]{3}{*}{ TC } & 25 & -2.80 & 13.76 & 46.93 & 0.892 \\
\hline & 35 & -3.13 & & & \\
\hline & 45 & -4.25 & & & \\
\hline \multirow[t]{3}{*}{ DC } & 25 & -3.33 & 7.06 & 26.08 & 0.977 \\
\hline & 35 & -3.69 & & & \\
\hline & 45 & -4.25 & & & \\
\hline
\end{tabular}




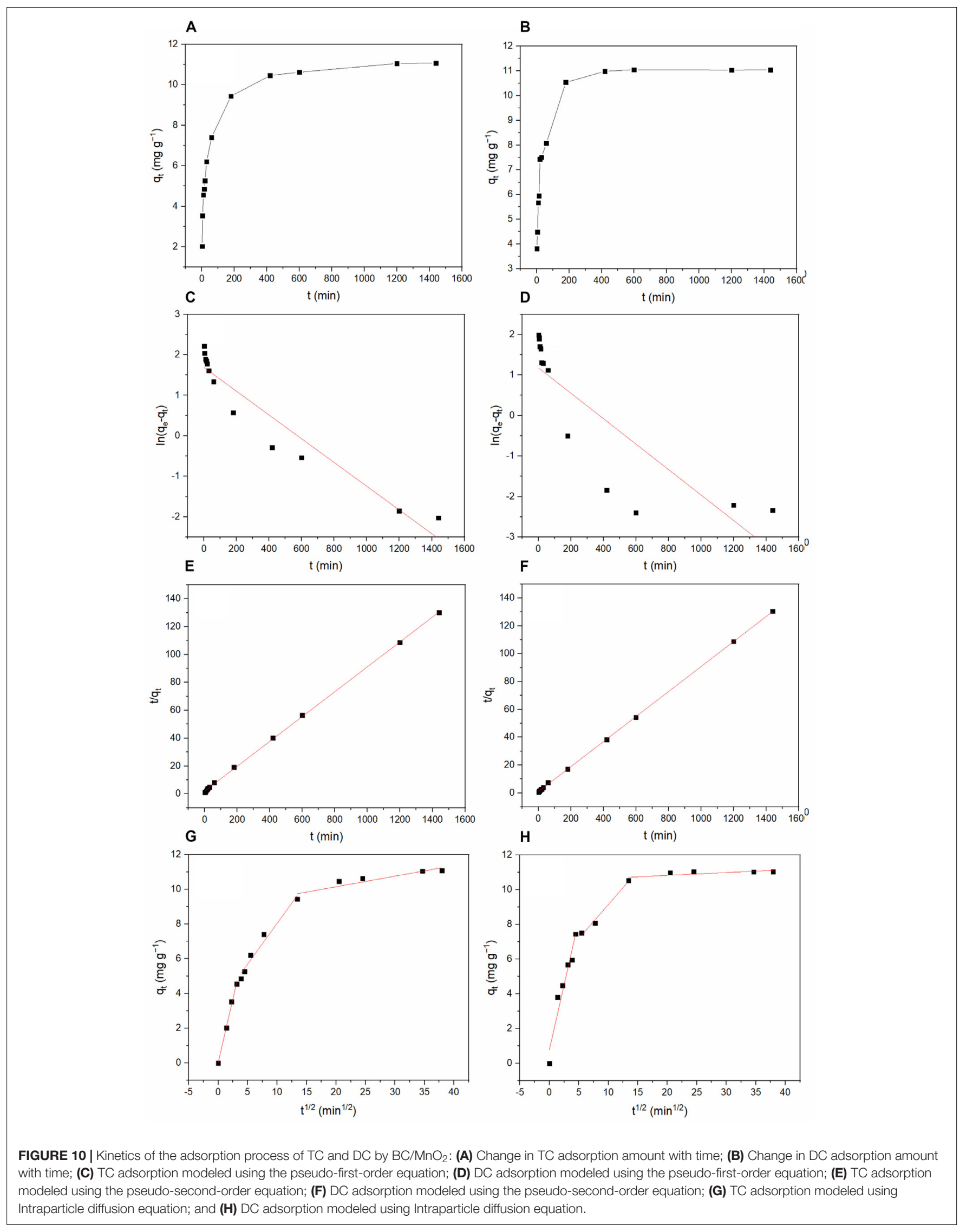


were used to analyze the results: a pseudo-first-order kinetic model and a pseudo-second-order kinetic model. Intra-particle diffusion model was further applied to determine the diffusion mechanisms and the rate controlling procedures.

The pseudo-first-level model is expressed as:

$$
\ln \left(q_{\mathrm{e}}-q_{\mathrm{t}}\right)=\ln q_{\mathrm{e}}-k_{1} t
$$

The pseudo-secondary model is expressed as:

$$
\frac{t}{q_{\mathrm{t}}}=\frac{1}{k_{2} q_{\mathrm{e}}^{2}}+\frac{t}{q_{\mathrm{e}}}
$$

Here, $q_{\mathrm{e}}$ is the removal amount at equilibrium $\left(\mathrm{mg} \cdot \mathrm{g}^{-1}\right) ; q_{t}$ is the removal amount at a given time $\mathrm{t}\left(\mathrm{mg} \cdot \mathrm{g}^{-1}\right) ; k_{1}$ is the adsorption rate constant of the pseudo-first-order model $\left(\mathrm{min}^{-1}\right)$; and $k_{2}$ is the adsorption rate constant of the pseudo-second-order model $\left(\mathrm{g} \cdot \mathrm{mg}^{-1} \cdot \min ^{-1}\right)$.

The intra-particle diffusion model is expressed as Zeng et al. (2018):

$$
q_{\mathrm{t}}=k_{\mathrm{id}} \mathrm{t}^{1 / 2}+c_{\mathrm{i}}
$$

Here, $q_{\mathrm{t}}\left(\mathrm{mg} \cdot \mathrm{g}^{-1}\right)$ is the removal amount at time $t, k_{\mathrm{id}}$ is the intra-particle diffusion rate constant $\left(\mathrm{mg} \cdot \mathrm{g}^{-1} \cdot \mathrm{min}^{-1 / 2}\right)$, and $c_{i}$ is the intercept related to the thickness of the boundary layer.

Figure 10 shows the results of the adsorption kinetics study. Table 4 lists the parameter values. The adsorption process reached equilibrium after $420 \mathrm{~min}$. Compared with the pseudofirst-order kinetic model, the adsorption data better fit the pseudo-second-order kinetic model $\left(R^{2}=0.999\right)$ (Turki et al., 2015). The pseudo-second-order kinetic model fitting results indicate that the process controlling the adsorption of TC and DC may be chemisorption (Tan et al., 2015). As shown in Figure 10 and Table 5, three linear portions were existed in the plots of $q_{\mathrm{t}}$ against $t^{1 / 2}$, suggesting that multiple steps including intra-particle diffusion and film diffusion were involved in the adsorption process.

\section{Regeneration of $\mathrm{BC} / \mathrm{MnO}_{2}$}

To investigate the regeneration ability of $\mathrm{BC} / \mathrm{MnO}_{2}$, several cycles of adsorption-desorption experiments were performed.

\begin{tabular}{|c|c|c|c|}
\hline \multirow{2}{*}{$\begin{array}{l}\text { Contaminants } \\
\text { TC }\end{array}$} & \multirow{2}{*}{$\begin{array}{l}\text { Kinetics } \\
\text { Pseudo-first-order }\end{array}$} & \multicolumn{2}{|c|}{ Parameters } \\
\hline & & $q_{e}\left(m g \cdot g^{-1}\right)$ & 5.41 \\
\hline & & $K_{1}\left(\min ^{-1}\right)$ & 0.0029 \\
\hline & & $R^{2}$ & 0.924 \\
\hline & Pseudo-second-order & $q_{\mathrm{e}}\left(\mathrm{mg} \cdot \mathrm{g}^{-1}\right)$ & 11.20 \\
\hline & & $K_{2}\left(g \cdot \mathrm{mg}^{-1} \cdot \mathrm{min}^{-1}\right)$ & 0.0041 \\
\hline & & $R^{2}$ & 0.999 \\
\hline \multirow[t]{6}{*}{ DC } & Pseudo-first-order & $q_{\mathrm{e}}\left(\mathrm{mg} \cdot \mathrm{g}^{-1}\right)$ & 3.25 \\
\hline & & $K_{1}\left(\min ^{-1}\right)$ & 0.0031 \\
\hline & & $R^{2}$ & 0.732 \\
\hline & Pseudo-second-order & $q_{\mathrm{e}}\left(\mathrm{mg} \cdot \mathrm{g}^{-1}\right)$ & 11.14 \\
\hline & & $K_{2}\left(g \cdot \mathrm{mg}^{-1} \cdot \mathrm{min}^{-1}\right)$ & 0.0085 \\
\hline & & $R^{2}$ & 0.999 \\
\hline
\end{tabular}

TABLE 4 | Model parameters and corresponding correlation coefficients of kinetics models.
TABLE 5 | Intra-particle diffusion parameters for the adsorption of TC and DC by $\mathrm{BC} / \mathrm{MnO}_{2}$.

\begin{tabular}{lccc}
\hline Contaminants & $\boldsymbol{k}_{\text {id }}\left(\mathbf{m g ~ g}^{\mathbf{- 1}} \cdot \mathbf{m i n}^{-\mathbf{0}} \mathbf{5}^{\mathbf{1}}\right)$ & $\boldsymbol{c}_{\boldsymbol{i}}$ & $\boldsymbol{R}_{\boldsymbol{i}}{ }^{2}$ \\
\hline TC & & & \\
Section1 & 1.47 & 0.02 & 0.997 \\
Section2 & 0.47 & 3.35 & 0.984 \\
Section3 & 0.06 & 8.92 & 0.929 \\
DC & & & \\
Section1 & 1.50 & 0.78 & 0.969 \\
Section2 & 0.39 & 5.23 & 0.995 \\
Section3 & 0.02 & 10.49 & 0.754
\end{tabular}

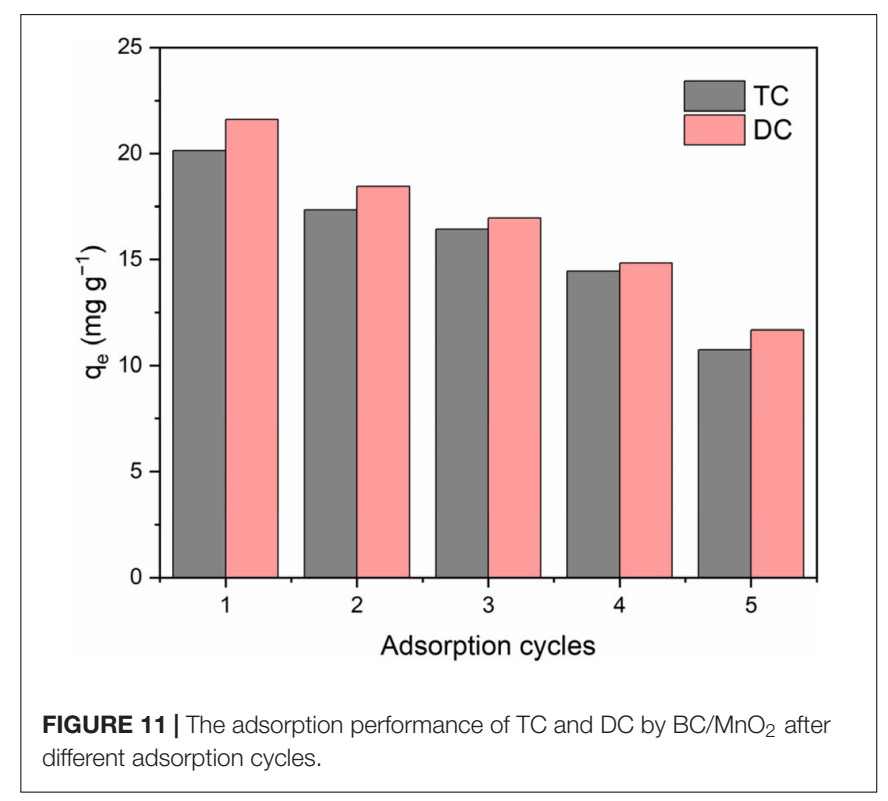

The TC and DC loaded $\mathrm{BC} / \mathrm{MnO}_{2}$ was desorbed using ethanol. The adsorption performance of $\mathrm{TC}$ and $\mathrm{DC}$ by $\mathrm{BC} / \mathrm{MnO}_{2}$ after different adsorption cycles are shown in Figure 11. The results indicated that the adsorption capacity of $\mathrm{BC} / \mathrm{MnO}_{2}$ decreased gradually with the increase of cycles. After five adsorption/desorption cycles, the adsorption amount of TC and $\mathrm{DC}$ onto the regenerated $\mathrm{BC} / \mathrm{MnO}_{2}$ still remained higher than the pristine biochar, indicating that $\mathrm{BC} / \mathrm{MnO}_{2}$ could be regenerated.

\section{CONCLUSION}

In this study, a biochar-supported nano manganese dioxide composite was prepared by loading manganese dioxide nanoparticles on biochar, with rice husk as the raw material. Compared with the original biochar, $\mathrm{MnO}_{2}$ nanoparticles appeared on the surface of $\mathrm{BC} / \mathrm{MnO}_{2}$, the carbon content decreased, and the oxygen content increased. $\mathrm{BC} / \mathrm{MnO}_{2}$ exhibited significantly larger total pore volume and specific surface area, and the pore structure of the biochar was improved. The comparative study about the adsorption ability of pristine biochar and $\mathrm{BC} / \mathrm{MnO}_{2}$ suggested that the loading of $\mathrm{MnO}_{2}$ was 
an effective way to improve the adsorption ability of biochar for TC and DC. The effects of $\mathrm{pH}$ on the adsorption of TC and $\mathrm{DC}$ by $\mathrm{BC} / \mathrm{MnO}_{2}$ were found to be insignificant. With an increase in the adsorbent dose, the removal rates of TC and $\mathrm{DC}$ increased, and the removal ability of $\mathrm{BC} / \mathrm{MnO}_{2}$ for $\mathrm{TC}$ was slightly higher than that for DC. Therefore, $\mathrm{BC} / \mathrm{MnO}_{2}$ may be an efficient material for TC and DC removal from aqueous solution. Further research about its efficiency for other antibiotics removal and deeper mechanisms should be studied.

\section{DATA AVAILABILITY STATEMENT}

The datasets generated for this study are available on request to the corresponding author.

\section{REFERENCES}

Ahmed, M. B., Zhou, J. L., Ngo, H. H., and Guo, W. (2015). Adsorptive removal of antibiotics from water and wastewater: Progress and challenges. Sci. Total Environ. 532, 112-126. doi: 10.1016/j.scitotenv.2015.05.130

Bose, V. C., and Biju, V. (2015). Mixed valence nanostructured Mn3O4 for supercapacitor applications. Bull. Mater. Sci. 38, 865-873. doi: 10.1007/s12034015-0906-z

Cai, X., Li, J., Liu, Y., Hu, X., Tan, X., Liu, S., et al. (2019). Design and preparation of chitosan-crosslinked bismuth ferrite/biochar coupled magnetic material for methylene blue removal. Int. J. Environ. Res. Public Health 17:6. doi: 10.3390/ ijerph17010006

Cai, X., Li, J., Liu, Y., Yan, Z., Tan, X., Liu, S., et al. (2018). Titanium dioxide-coated biochar composites as adsorptive and photocatalytic degradation materials for the removal of aqueous organic pollutants. J. Chem. Technol. Biotechnol. 93, 783-791. doi: $10.1002 /$ jctb. 5428

Carvalho, I. T., and Santos, L. (2016). Antibiotics in the aquatic environments: a review of the European scenario. Environ. Int. 94, 736-757. doi: 10.1016/j. envint.2016.06.025

Cui, L., Wang, Y., Gao, L., Hu, L., Yan, L., Wei, Q., et al. (2015). EDTA functionalized magnetic graphene oxide for removal of $\mathrm{Pb}(\mathrm{II}), \mathrm{Hg}(\mathrm{II})$ and $\mathrm{Cu}(\mathrm{II})$ in water treatment: adsorption mechanism and separation property. Chem. Eng. J. 281, 1-10. doi: 10.1016/j.cej.2015.06.043

Drury, B., Scott, J., Rosi-Marshall, E. J., and Kelly, J. J. (2013). Triclosan exposure increases triclosan resistance and influences taxonomic composition of benthic bacterial communities. Environ. Sci. Technol. 47, 8923-8930. doi: 10.1021/ es401919k

Frieri, M., Kumar, K., and Boutin, A. (2017). Antibiotic resistance. J. Infect. Public Heal. 10, 369-378. doi: 10.1016/j.jiph.2016.08.007

Han, H. S., You, J.-M., Jeong, H., and Jeon, S. (2013). Synthesis of graphene oxide grafted poly(lactic acid) with palladium nanoparticles and its application to serotonin sensing. Appl. Surf. Sci. 284, 438-445. doi: 10.1016/j.apsusc.2013. 07.116

Homem, V., and Santos, L. (2011). Degradation and removal methods of antibiotics from aqueous matrices - A review. J. Environ. Manage. 92, 23042347. doi: 10.1016/j.jenvman.2011.05.023

Hong, P., Al-Jassim, N., Ansari, I. M., and Mackie, I. R. (2013). Environmental and public health implications of water reuse: antibiotics, antibiotic resistant bacteria, and antibiotic resistance genes. Antibiotics 2, 367-399. doi: 10.3390/ antibiotics 2030367

Hou, J., Wang, C., Mao, D., and Luo, Y. (2016). The occurrence and fate of tetracyclines in two pharmaceutical wastewater treatment plants of Northern China. Environ. Sci. Pollut. Res. 23, 1722-1731. doi: 10.1007/s11356-015-5 431-5

Huang, D., Guo, X., Peng, Z., Zeng, G., Xu, P., Gong, X., et al. (2018). White rot fungi and advanced combined biotechnology with nanomaterials: promising tools for endocrine-disrupting compounds biotransformation. Crit. Rev. Biotechnol. 38, 671-689. doi: 10.1080/07388551.2017.1386613

\section{AUTHOR CONTRIBUTIONS}

$\mathrm{JL}$ and XC contributed conception and design of the study. YL and YG organized the database. HW, ShaL, SimL, YY, and SijL performed the statistical analysis. All authors contributed to manuscript revision, read and approved the submitted version.

\section{FUNDING}

This study was financially supported by the National Natural Science Foundation of China (Grant No. 51909283) and the Natural Science Foundation of Hunan Province, China (Grant No. 2018JJ3096).

Huang, X., Liu, C., Li, K., Su, J., Zhu, G., and Liu, L. (2015). Performance of vertical up-flow constructed wetlands on swine wastewater containing tetracyclines and tet genes. Water Res. 70, 109-117. doi: 10.1016/j.watres.2014. 11.048

Jing, X., Wang, Y., Liu, W., Wang, Y., and Jiang, H. (2014). Enhanced adsorption performance of tetracycline in aqueous solutions by methanol-modified biochar. Chem. Eng. J. 248, 168-174. doi: 10.1016/j.cej.2014.03.006

Kasprzyk-Hordern, B., Dinsdale, R. M., and Guwy, A. J. (2009). The removal of pharmaceuticals, personal care products, endocrine disruptors and illicit drugs during wastewater treatment and its impact on the quality of receiving waters. Water Res. 43, 363-380. doi: 10.1016/j.watres.2008.10.047

Li, H., Huang, G., Zhang, J., Fu, S., Wang, T., and Liao, H. (2017). Photochemical synthesis and enhanced photocatalytic activity of $\mathrm{MnOx} / \mathrm{BiPO} 4$ heterojunction. Trans. Nonferrous Met. Soc. China 27, 1127-1133. doi: 10.1016/S1003-6326(17) 60131-6

Li, K., Yediler, A., Yang, M., Schulte-Hostede, S., and Wong, M. H. (2008). Ozonation of oxytetracycline and toxicological assessment of its oxidation by-products. Chemosphere 72, 473-478. doi: 10.1016/j.chemosphere.2008.0 2.008

Li, R., Yu, L., Li, S., Fan, J., Luo, R., and Zhao, J. (2018). Facile synthesis of hierarchical mesoporous beta-manganese dioxide nanoflowers with extremely high specific surface areas for high-performance electrochemical capacitors. Electrochim. Acta 284, 52-59. doi: 10.1016/j.electacta.2018.07.172

Liang, J., Li, X., Yu, Z., Zeng, G., Luo, Y., Jiang, L., et al. (2017). Amorphous $\mathrm{MnO} 2$ modified biochar derived from aerobically composted swine manure for adsorption of $\mathrm{Pb}(\mathrm{II})$ and Cd(II). ACS Sustainable Chem. Eng. 5, 5049-5058. doi: 10.1021/acssuschemeng.7b00434

Liu, S., Liu, Y., Tan, X., Liu, S., Li, M., Liu, N., et al. (2019). Facile synthesis of MnOx-loaded biochar for the removal of doxycycline hydrochloride: effects of ambient conditions and co-existing heavy metals. J. Chem. Technol. Biotechnol. 94, 2187-2197. doi: 10.1002/jctb.6000

Lu, X., Wang, Y., Zhang, X., Xu, G., Wang, D., Lv, J., et al. (2018). NiS and MoS2 nanosheet co-modified graphitic C3N4 ternary heterostructure for high efficient visible light photodegradation of antibiotic. J. Hazard. Mater. 341, 10-19. doi: 10.1016/j.jhazmat.2017.07.004

Luo, Y., Xu, L., Rysz, M., Wang, Y., Zhang, H., and Alvarez, P. J. J. (2011). Occurrence and transport of tetracycline, sulfonamide, quinolone, and macrolide antibiotics in the Haihe River Basin, China. Environ. Sci. Technol. 45, 1827-1833. doi: 10.1021/es104009s

Ma, C., Huang, H., Gao, X., Wang, T., Zhu, Z., Huo, P., et al. (2018). Honeycomb tubular biochar from fargesia leaves as an effective adsorbent for tetracyclines pollutants. J. Taiwan Inst. Chem. Eng. 91, 299-308. doi: 10.1016/j.jtice.2018.0 5.032

Mahamallik, P., Saha, S., and Pal, A. (2015). Tetracycline degradation in aquatic environment by highly porous $\mathrm{MnO} 2$ nanosheet assembly. Chem. Eng. J. 276, 155-165. doi: 10.1016/j.cej.2015.04.064

Medernach, R. L., and Logan, L. K. (2018). The growing threat of antibiotic resistance in children. Infect. Dis. Clin. 32, 1-17. doi: 10.1016/j.idc.2017.11.001 
Organization, W. H. (2014). Antimicrobial Resistance: Global Report on Surveillance. Geneva: World Health Organization.

Petrie, B., Barden, R., and Kasprzyk-Hordern, B. (2015). A review on emerging contaminants in wastewaters and the environment: Current knowledge, understudied areas and recommendations for future monitoring. Water Res. 72, 3-27. doi: 10.1016/j.watres.2014.08.053

Saiah, F. B. D., Su, B.-L., and Bettahar, N. (2009). Nickel-iron layered double hydroxide (LDH): Textural properties upon hydrothermal treatments and application on dye sorption. J. Hazard. Mater. 165, 206-217. doi: 10.1016/j. jhazmat.2008.09.125

Sarmah, A. K., Meyer, M. T., and Boxall, A. B. A. (2006). A global perspective on the use, sales, exposure pathways, occurrence, fate and effects of veterinary antibiotics (VAs) in the environment. Chemosphere 65, 725-759. doi: 10.1016/j. chemosphere.2006.03.026

Sharma, V. K., Johnson, N., Cizmas, L., McDonald, T. J., and Kim, H. (2016). A review of the influence of treatment strategies on antibiotic resistant bacteria and antibiotic resistance genes. Chemosphere 150, 702-714. doi: 10.1016/j. chemosphere.2015.12.084

Shete, P. B., Patil, R. M., Tiwale, B. M., and Pawar, S. H. (2015). Water dispersible oleic acid-coated $\mathrm{Fe} 3 \mathrm{O} 4$ nanoparticles for biomedical applications. J. Magn. Magn. Mater. 377, 406-410. doi: 10.1016/j.jmmm.2014.10.137

Song, Z., Lian, F., Yu, Z., Zhu, L., Xing, B., and Qiu, W. (2014). Synthesis and characterization of a novel $\mathrm{MnOx}$-loaded biochar and its adsorption properties for Cu2+ in aqueous solution. Chem. Eng. J. 242, 36-42. doi: 10.1016/j.cej.2013. 12.061

Tan, X., Liu, S., Liu, Y., Gu, Y., Zeng, G., Cai, X., et al. (2016a). One-pot synthesis of carbon supported calcined- $\mathrm{Mg} / \mathrm{Al}$ layered double hydroxides for antibiotic removal by slow pyrolysis of biomass waste. Sci. Rep. 6:39691. doi: 10.1038/ srep39691

Tan, X., Liu, Y., Gu, Y., Xu, Y., Zeng, G., Hu, X., et al. (2016b). Biochar-based nanocomposites for the decontamination of wastewater: a review. Bioresour. Technol. 212, 318-333. doi: 10.1016/j.biortech.2016.04.093

Tan, X., Liu, Y., Zeng, G., Wang, X., Hu, X., Gu, Y., et al. (2015). Application of biochar for the removal of pollutants from aqueous solutions. Chemosphere 125, 70-85. doi: 10.1016/j.chemosphere.2014.12.058

Turki, A., Guillard, C., Dappozze, F., Ksibi, Z., Berhault, G., and Kochkar, H. (2015). Phenol photocatalytic degradation over anisotropic $\mathrm{TiO} 2$ nanomaterials: Kinetic study, adsorption isotherms and formal mechanisms. Appl. Catal. B Environ. 163, 404-414. doi: 10.1016/j.apcatb.2014.08.010

Tyson, B. M., Abu Al-Rub, R. K., Yazdanbakhsh, A., and Grasley, Z. (2011). A quantitative method for analyzing the dispersion and agglomeration of nanoparticles in composite materials. Compos. Pt. B Eng. 42, 1395-1403. doi: 10. 1016/j.compositesb.2011.05.020

Wang, H., Yuan, X., Wu, Y., Zeng, G., Dong, H., Chen, X., et al. (2016). In situ synthesis of In2S3@MIL-125(Ti) core-shell microparticle for the removal of tetracycline from wastewater by integrated adsorption and visible-light-driven photocatalysis. Appl. Catal. B Environ. 186, 19-29. doi: 10.1016/j.apcatb.2015. 12.041

Wang, S., Xiao, L., Fang, Z., Qiu, G., and Wang, C. (2010). Electrogenerative leaching for sphalerite- $\mathrm{MnO} 2$ in the presence of Acidithiobacillus thiooxidans. Trans. Nonferrous Met. Soc. China 20, s21-s25. doi: 10.1016/S1003-6326(10) 60005-2

Wu, Y., Zhang, P., Zhang, H., Zeng, G., Liu, J., Ye, J., et al. (2016). Possibility of sludge conditioning and dewatering with rice husk biochar modified by ferric chloride. Bioresour. Technol. 205, 258-263. doi: 10.1016/j.biortech.2016. 01.020

Wu, Z., Zhong, H., Yuan, X., Wang, H., Wang, L., Chen, X., et al. (2014). Adsorptive removal of methylene blue by rhamnolipid-functionalized graphene oxide from wastewater. Water Res. 67, 330-344. doi: 10.1016/j.watres.2014. 09.026

Xiao, L., Fang, Z., Qiu, G., Wang, S., and Wang, C. (2010). Mechanism of electrogenerative-leaching of chalcopyrite- $\mathrm{MnO} 2$ in presence of Acidithiobacillus ferrooxidans. Trans. Nonferrous Met. Soc. China 20, s15-s20. doi: 10.1016/ S1003-6326(10)60004-0
Xie, G., Liu, X., Li, Q., Lin, H., Li, Y., Nie, M., et al. (2017). The evolution of $\alpha-\mathrm{MnO} 2$ from hollow cubes to hollow spheres and their electrochemical performance for supercapacitors. J. Mater. Sci. 52, 10915-10926. doi: 10.1007/ s10853-017-1116-4

Xiong, W., Zeng, Z., Li, X., Zeng, G., Xiao, R., Yang, Z., et al. (2019). Ni-doped MIL-53(Fe) nanoparticles for optimized doxycycline removal by using response surface methodology from aqueous solution. Chemosphere 232, 186-194. doi: 10.1016/j.chemosphere.2019.05.184

Ye, S., Zeng, G., Tan, X., Wu, H., Liang, J., Song, B., et al. (2020). Nitrogendoped biochar fiber with graphitization from Boehmeria nivea for promoted peroxymonosulfate activation and non-radical degradation pathways with enhancing electron transfer. Appl. Catal. B Environ. 269:118850. doi: 10.1016/j. apcatb.2020.118850

Yin, X., Liu, X., Zhan, Y., Zhang, H., and Chen, Q. (2015). Effect of Ag addition on the magnetic and electrical properties of $\mathrm{La} 0.67 \mathrm{Ca} 0.33 \mathrm{MnO} 3$ films. Appl. Surf. Sci. 349, 983-987. doi: 10.1016/j.apsusc.2015.04.218

Yu, F., Li, Y., Han, S., and Ma, J. (2016). Adsorptive removal of antibiotics from aqueous solution using carbon materials. Chemosphere 153, 365-385. doi: 10. 1016/j.chemosphere.2016.03.083

Yu, J., Tong, M., Sun, X., and Li, B. (2007). A simple method to prepare poly(amic acid)-modified biomass for enhancement of lead and cadmium adsorption. Biochem. Eng. J. 33, 126-133. doi: 10.1016/j.bej.2006.10.012

Zeng, Z., Tan, X., Liu, Y., Tian, S., Zeng, G., Jiang, L., et al. (2018). Comprehensive adsorption studies of doxycycline and ciprofloxacin antibiotics by biochars prepared at different temperatures. Front. Chem. 6:80. doi: 10.3389/fchem.2018. 00080

Zeng, Z., Ye, S., Wu, H., Xiao, R., Zeng, G., Liang, J., et al. (2019). Research on the sustainable efficacy of g-MoS2 decorated biochar nanocomposites for removing tetracycline hydrochloride from antibiotic-polluted aqueous solution. Sci. Total Environ. 648, 206-217. doi: 10.1016/j.scitotenv.2018.08.108

Zhang, P., Liu, S., Tan, X., Liu, Y., Zeng, G., Yin, Z., et al. (2019a). Microwaveassisted chemical modification method for surface regulation of biochar and its application for estrogen removal. Process Saf. Environ. Prot. 128, 329-341. doi: 10.1016/j.psep.2019.06.009

Zhang, P., Tan, X., Liu, S., Liu, Y., Zeng, G., Ye, S., et al. (2019b). Catalytic degradation of estrogen by persulfate activated with iron-doped graphitic biochar: Process variables effects and matrix effects. Chem. Eng. J. 378:122141. doi: 10.1016/j.cej.2019.122141

Zhang, Y., Hu, S., Zhang, H., Shen, G., Yuan, Z., and Zhang, W. (2017). Degradation kinetics and mechanism of sulfadiazine and sulfamethoxazole in an agricultural soil system with manure application. Sci. Total Environ. 607-608, 1348-1356. doi: 10.1016/j.scitotenv.2017.07.083

Zhang, Y., Xing, Z., Duan, Z., Meng, L., and Wang, Y. (2014). Effects of steam activation on the pore structure and surface chemistry of activated carbon derived from bamboo waste. Appl. Surf. Sci. 315, 279-286. doi: 10.1016/j.apsusc. 2014.07.126

Zhang, Z., Gao, P., Cheng, J., Liu, G., Zhang, X., and Feng, Y. (2018). Enhancing anaerobic digestion and methane production of tetracycline wastewater in EGSB reactor with GAC/NZVI mediator. Water Res. 136, 54-63. doi: 10.1016/j. watres.2018.02.025

Zheng, H., Wang, Z., Zhao, J., Herbert, S., and Xing, B. (2013). Sorption of antibiotic sulfamethoxazole varies with biochars produced at different temperatures. Environ. Pollut. 181, 60-67. doi: 10.1016/j.envpol.2013.05.056

Conflict of Interest: The authors declare that the research was conducted in the absence of any commercial or financial relationships that could be construed as a potential conflict of interest.

Copyright $\odot 2020 \mathrm{Li}$, Cai, Liu, Gu, Wang, Liu, Liu, Yin and Liu. This is an open-access article distributed under the terms of the Creative Commons Attribution License (CC BY). The use, distribution or reproduction in other forums is permitted, provided the original author(s) and the copyright owner(s) are credited and that the original publication in this journal is cited, in accordance with accepted academic practice. No use, distribution or reproduction is permitted which does not comply with these terms. 